\title{
INHIBITORY ACTION OF 6-ETHYL-3-(1H-TETRAZOL-5-YL) CHROMONE (AA-344) ON IgE-, IgGa- OR CHEMICAL AGENT-INDUCED HISTAMINE RELEASE FROM ISOLATED RAT MAST CELLS
}

\author{
Taketoshi SAIJO, Yasuko ASHIDA, Hisashi KURIKI, \\ Morio KANNO* and Yoshitaka MAKI \\ Medicinal Research Laboratories, Central Research Division, \\ Takeda Chemical Industries, Ltd., Yodogawa-ku, Osaka 532, Japan
}

Accepted March 8, 1979

\begin{abstract}
The antiallergic action of 6-ethyl-3-(1H-tetrazol-5-yl)chromone (AA-344) was studied on isolated rat peritoneal mast cells. AA-344 clearly inhibited the IgEmediated release of histamine caused by various concentrations of antigen and the $50 \%$ inhibitory concentration was $0.1 \mu \mathrm{M}$. On the IgGa-mediated release of histamine, a peak inhibition of AA-344 was observed at $10 \mu \mathrm{M}$. The histamine release induced by chemical agents such as concanavalin $\mathrm{A}$, dextran and compound $48 / 80$ was depressed by AA-344 at the range of $0.1-1 \mathrm{mM}$. The results obtained in this study indicate that the antiallergic action of AA-344 is due to selective inhibition on the immunological release of the chemical mediator from mast cells.
\end{abstract}

In a previous study, we found that 6-ethyl-3-(1H-tetrazol-5-yl) chromone (AA-344) inhibits markedly the IgE-mediated passive cutaneous anaphylaxis (PCA) and partially the IgGa-mediated PCA in rats (1). Both PCA reactions are caused by chemical mediators such as histamine released from mast cells as a result of the immunological reaction $(2,3)$. We have suggested that the inhibitory action of AA-344 on the PCA may be due to inhibition of the release of the chemical mediators from the mast cells, because AA-344 has no antagonistic action on either histamine or serotonin (1). The present study was done to evaluate the in vitro inhibitory effect of AA-344 on the release of histamine from isolated rat peritoneal mast cells mediated by IgE and IgGa antibodies or that induced by chemical agents. The activity and mode of the action of AA-344 were compared with those of disodium cromoglycate.

\section{MATERIALS AND METHODS}

Animal: Male Sprague-Dawley rats weighing 250-350 g (8-10 weeks old) were used.

Antigens: Ascaris extract (asc) was prepared from Ascaris sum obtained from miniature swine according to the method of Tada and Okumura (4). Dinitrophenylated asc (DNPasc) was prepared by the method of Little and Eisen (5). Egg albumin (EA) of hen egg white was purified 3 times with sodium sulfate solution (6).

* Present Address: Department of Pharmacology, School of Medicine, Hokkaido University, Sapporo 060, Japan 
Antisera: Rat anti-DNP-asc antiserum containing IgE (anti-DNP-asc) and rat anti-EA antiserum containing IgGa (anti-EA) were prepared as described previously (1). The titer of anti-DNP-asc, i.e. the highest dilution inducing PCA in rats after a 48-hr latent period, was $1: 32$. The titer of anti-EA heated at $56^{\circ} \mathrm{C}$ for $4 \mathrm{hr}$ was $1: 16$; however, this antiserum was found to contain no IgE as evidenced by its inability to induce the 48-hr PCA at 2-fold dilution.

Mcdia: Mast cell medium (MCM) was prepared by the method of Sullivan et al. (7): the composition was $150 \mathrm{mM} \mathrm{NaCl}, 3.7 \mathrm{mM} \mathrm{KCl}, 3 \mathrm{mM} \mathrm{Na}_{2} \mathrm{HPO}_{4}, 3.5 \mathrm{mM} \mathrm{KH} \mathrm{KHO}_{4}, 1 \mathrm{mM}$ $\mathrm{CaCl}_{2}, 5.6 \mathrm{mM}$ glucose, $0.1 \%$ bovine serum albumin, $10 \mathrm{U} / \mathrm{ml}$ of heparin and $0.1 \%$ gelatin in distilled water, $\mathrm{pH}$ 6.8. In the experiment of dextran-induced histamine release, the modified MCM used was one in which glucose was excluded and the concentration of $\mathrm{CaCl}_{2}$ was increased from $1 \mathrm{mM}$ to $3 \mathrm{mM}$.

Compounds: The following histamine releasers and stimulants were used: concanavalin A (Miles), dextran T-2000 (mean molecular weight $2 \times 10^{6}$, Pharmacia), compound 48/80 (Sigma), phosphatidylserine (NBC) and deuterium oxide $\left(\mathrm{D}_{2} \mathrm{O}, \mathrm{CEA}\right)$. AA-344 was dissolved in sodium bicarbonate solution. Disodium cromoglycate (DSCG; Intal ${ }^{\circledR}$, Fisons) and the above compounds were dissolved in MCM or modified MCM.

Rat peritoncal cells and purified mast cells: Rat peritoneal mast cells were obtained according to the method of Sullivan et al. (7). The rats were decapitated and given $16 \mathrm{ml}$ of MCM i.p. and their abdomens were massaged 100 times. Harvest of the peritoneal cell suspension contained an average of $10^{6}$ mast cells per rat. The polycarbonate tube containing the suspension was centrifuged at $50 \mathrm{~g}$ for $7 \mathrm{~min}$. The sedimented peritoneal cells were suspended and passively sensitized with the antisera for experiments on the immunological histamine release. The purified mast cells prepared as described below failed to be sensitized with each of anti-DNP-ase and anti-EA, the reason of which was unclear. On the other hand, the peritoneal cells were purified by the following procedures for the experiments of histamine release induced by chemical agents: $2 \mathrm{ml}$ of the peritoneal cell suspension obtained from 5 rats was layered over $4 \mathrm{ml}$ of $38 \%(\mathrm{w} / \mathrm{v})$ bovine serum albumin in $\mathrm{MCM}$ placed in a $50 \mathrm{ml}$ polycarbonate centrifuge tube. The tube was allowed to stand at room temp. for $25 \mathrm{~min}$, followed by centrifugation at $450 \mathrm{~g}$ for $20 \mathrm{~min}$. The mast cells sedimented at the bottom were washed twice with MCM, counted and adjusted to the desired concentration with MCM. Purity of the mast cells in the final preparation was $85-90 \%$. These cells were identified by staining the cytoplasmic granules with $0.05 \%$ toluidine blue.

IgE- or IgGa-mediated histamine release: Sensitization of the rat peritoneal cells with anti-DNP-asc was achieved according to the method of Austen et al. (8). The cell suspension containing the mast cells $\left(5 \times 10^{6}\right)$ was incubated with $2 \mathrm{ml}$ of antiserum and $2 \mathrm{mg}$ of heparin at $37^{\circ} \mathrm{C}$ for $2.5 \mathrm{hr}$ with a gentle agitation every $10 \mathrm{~min}$ to maintain a uniform suspension. At the end of the sensitization period, $2 \mathrm{ml}$ of $\mathrm{MCM}$ was added to the incubation medium and the suspension centrifuged at $50 \mathrm{~g}$ for $10 \mathrm{~min}$. The cells sedimented were washed once with $40 \mathrm{ml}$ of MCM, and resuspended in MCM at a desired concentration. The suspension of the peritoneal cells containing the sensitized mast cells $\left(2 \times 10^{5}\right)$ in MCM was equilibrated 
at $37^{\circ} \mathrm{C}$ for $10 \mathrm{~min}$ and incubated for an additional $10 \mathrm{~min}$ with $10 \mu \mathrm{g}$ of DNP-asc in a total volume of $1 \mathrm{ml}$. Either AA-344 or DSCG was added simultaneously with antigen. Another experiment in the presence of $\mathrm{D}_{2} \mathrm{O}$, which enhances microtubule formation, was performed to evaluate the action of AA-344 on an intracellular process of the IgE-mediated histamine release in which the microtubules participated.

Studies on the IgGa-mediated histamine release were performed without preincubation of the peritoneal cells with antiserum for the sensitization. The peritoneal cells containing the mast cells $\left(3 \times 10^{5}\right)$ were suspended in $0.1 \mathrm{ml}$ of anti-EA, $0.05 \mathrm{ml}$ of EA $(100 \mu \mathrm{g})$, and $0.1 \mathrm{ml}$ of the drug solution or MCM. The mixture was incubated at $37^{\circ} \mathrm{C}$ for $1 \mathrm{hr}$ and then $0.75 \mathrm{ml}$ of cold MCM $\left(4^{\circ} \mathrm{C}\right)$ was added to stop the reaction. Both the IgE- and IgGamediated histamine releases were depressed by adding calcium chelating agents at the concentration of 1-10 mM, or $0.1 \mathrm{M}$ 2-deoxyglucose, or by lowering the temp. of the incubation bath to $4{ }^{\circ} \mathrm{C}$. Moreover, these immunological reactions occurred without loss of the lactate dehydrogenase activity from the cells (determined by LDH B-Test Wako kit), indicating that these are non-cytotoxic reactions.

Histamine release induced by chemical agents: Concanavalin A-induced histamine release was studied according to the method of Sullivan et al. (9). The purified mast cells $\left(1.7 \times 10^{5}\right)$ suspended in MCM were equilibrated at $37^{\circ} \mathrm{C}$ for 5 min and then incubated with $10 \mu \mathrm{g}$ of concanavalin A for an additional $20 \mathrm{~min}$. Thereafter, the reaction mixture was incubated with $10 \mu \mathrm{g}$ of phosphatidylserine (PS) at $37^{\circ} \mathrm{C}$ for $15 \mathrm{~min}$. AA-344 or DSCG was added simultaneously with concanavalin A. Dextran-induced histamine release was studied by incubating with purified mast cells $\left(10^{5}\right)$ in the presence of $50 \mu \mathrm{g}$ of PS at $37^{\circ} \mathrm{C}$ for $10 \mathrm{~min}$, and then with $5 \mathrm{mg}$ dextran for an additional $15 \mathrm{~min}$. Drugs were added simultaneously with PS. A study on compound 48/80-induced histamine release was carried out by incubating the purified mast cells $\left(10^{5}\right)$ with $0.25 \mu \mathrm{g}$ of compound $48 / 80$ and drugs at $37^{\circ} \mathrm{C}$ for $15 \mathrm{~min}$. The total volume of the incubation mixture was maintained at $1 \mathrm{ml}$.

Histamine assay: Histamine was measured by the fluorometric method of Shore et al. (10). The intracellular and extracellular histamine in suspension of the peritoneal cells or purified mast cells was measured after boiling for $15 \mathrm{~min}$ with or without preceding centrifugation. The results were expressed in terms of $\mu \mathrm{g}$ histamine per $10^{6}$ mast cells. The combined amount of the released and residual histamine corresponded to the total histamine present in the original specimen.

Statistical analyses: Experimental results were expressed as mean values $\_$the standard errors (S.E.). Statistical comparison between groups was made by Student's $t$-test.

\section{RESULTS}

IgE-mediated histamine release: The release of histamine from the rat peritoneal mast cells sensitized with the anti-DNP-asc increased in proportion to the concentration of DNPasc added at the range of $0.01-10 \mu \mathrm{g}$ (Fig. 1): the release by $10 \mu \mathrm{g}$ of antigen was approx. $20 \%$ of the total histamine content in cells. A $0.3 \mu \mathrm{M} \mathrm{AA}-344$ or DSCG added simultaneously with the antigen markedly depressed the immunological release of histamine 


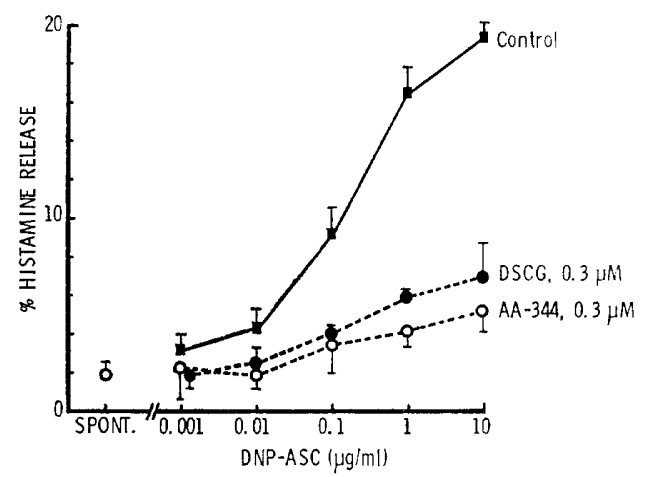

Fig. 1. Effects of AA-344 and DSCG on the histamine release induced by various concentrations of antigen from the rat sensitized peritoneal cells. The cells were passively sensitized with anti-DNP-ase and challenged with DNP-asc. Reaction mixture of $1 \mathrm{ml}$ in a total volume contained $1.8 \times 10^{5}$ mast cells. The total histamine was $20.5 \pm 2.3 \mu \mathrm{g} / 10^{5}$ mast cells. Spontaneous histamine release occurring in the absence of antigen was $1.9 \pm 0.4 \%$. Each value represents mean \pm S.E. of $3-5$ experiments.

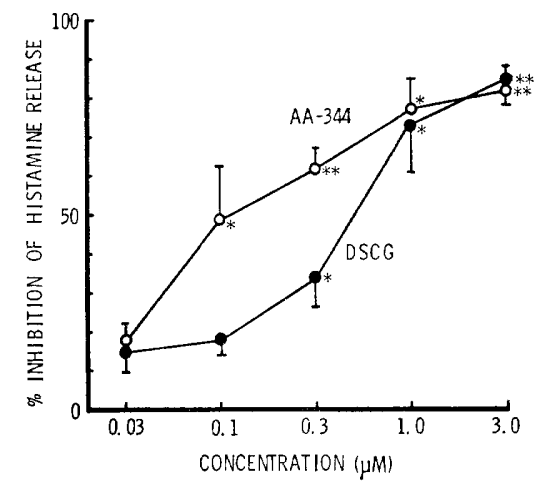

FIG. 2. Effects of AA-344 and DSCG on the lgE-mediated histamine release from the rat sensitized peritoneal cells. The cells were passively sensitized with anti-DNPasc and challenged with $10 \mu \mathrm{g}$ DNP-asc. Reaction mixture of $1 \mathrm{ml}$ in a total volume contained $1.7 \times 10^{5}$ mast cells. The total histamine was $19.2 \pm 2.5 \mu \mathrm{g} / 10^{6}$ mast cells. Histamine release induced by DNP-ase and spontaneous histamine release occurring in the absence of antigen were $24.1 \pm 6.1 \%$ and $2.9 \pm 0.8 \%$, respectively. Each point represents mean \pm S.E. of 3-6 experiments. $* \mathbf{P}<0.05,{ }^{* * *} \mathbf{P}<0.01$ vs. immunological histamine release without drug addition.

induced by various concentrations of antigen (Fig. 1). The IgE-mediated histamine release provoked by $10 \mu \mathrm{g}$ of DNP-asc was evidently depressed by $0.03-1 \mu \mathrm{M} \mathrm{AA}-344$ or $0.1-3 \mu \mathrm{M}$ DSCG in a concentration-dependent manner (Fig. 2). The IC50 value, i.e. the concentration which induced a $50 \%$ inhibition of the histamine release, was $0.1 \mu \mathrm{M}$ for AA-344 or $0.5 \% \mathrm{M}$ for DSCG, indicating that AA-344 was 5 times as potent as DSCG.

In the presence of 10 and $25 \% \mathrm{D}_{2} \mathrm{O}$ which stimulates the assembly of tubulin into microtubules, the IgE-mediated histamine release was enhanced 1.6 and 2.8 times of the control, respectively, whereas $25 \% \mathrm{D}_{2} \mathrm{O}$ alone did not induce the histamine release. AA-344 and DSCG at the range of $0.1-10 \mu \mathrm{M}$ exerted a concentration-dependent inhibition of the immunological histamine release enhanced by $25 \% \mathrm{D}_{2} \mathrm{O}$ (Fig. 3). The inhibitory concentration of these compounds in the presence of $25 \% \mathrm{D}_{2} \mathrm{O}$ was approx. 10 times higher than that in the absence of $\mathrm{D}_{2} \mathrm{O}$. The inhibitory effect of colchicine (Merck), a compound known to disrupt the microtubules, was observed consistently regardless of the presence or absence of $\mathrm{D}_{2} \mathrm{O}$.

IgGa-mediated histamine release: The mast cells sensitized with anti-EA containing IgGa showed approx. $30 \%$ release of histamine when challenged with $100 \mu \mathrm{g}$ of EA, but there was no release of lactate dehydrogenase. Furthermore, no histamine release from the peritoneal cells occurred with the addition of normal rat serum heated at $56^{\circ} \mathrm{C}$ for $4 \mathrm{hr}$. Under this condition, the effect of AA-344 or DSCG on the IgGa-mediated histamine release was determined (Fig. 4). The release of histamine was significantly inhibited by 


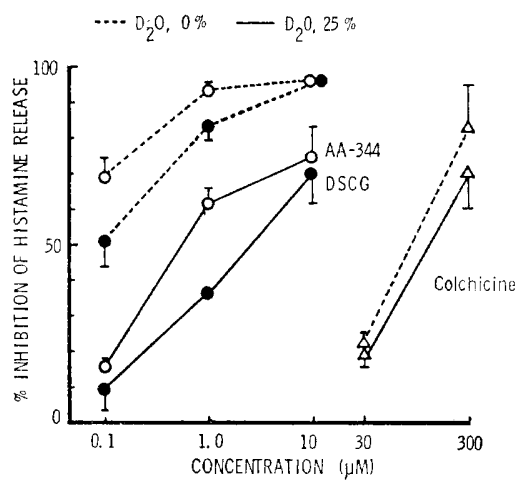

Fig. 3. Effects of AA-344, DSCG and colchicine on the IgE-mediated immunological histamine release enhanced by $\mathrm{D}_{2} \mathrm{O}$ from the rat peritoneal cells. The cells were passively sensitized with anti-DNP-asc. The spontaneous and immunological histamine releases in the absence of $\mathrm{D}_{2} \mathrm{O}$ were $2.0 \pm 0.1 \%$ and $32.2 \pm 4.0 \%$ of the total histamine content ( $16.5+2.3 \mu \mathrm{g} / 10^{\circ}$ mast cells). The immunological histamine releases in the presence of $10 \%$ and $25 \%$ $\mathrm{D}_{2} \mathrm{O}$ were $52.9-5.7 \%$ and $89.1 \pm 5.6 \%$, respectively. AA-344, DSCG or colchicine was added simultaneously with antigen and $\mathrm{D}_{2} \mathrm{O}$. Each point represents mean $\mathrm{t}$ S.E. of 3 experiments.

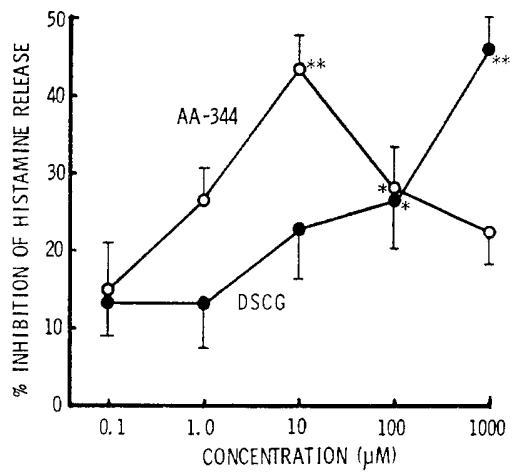

FG. 4. Efrects of AA-344 and DSCG on IgGamediated histamine release from the rat sensitized peritoneal cells. Immunological histamine release induced by $100 \mu \mathrm{g}$ EA and spontaneous histamine relcase from the peritoneal cells sensitized with anti-EA containing IgGa were $29.2-2.0 \%$ and $4.3-1.3 \%$ of the total histamine content (12.5 $1.6 \mu \mathrm{g} / 10^{6}$ mast cells). Reaction mixture of $0.25 \mathrm{ml}$ in a total volume contained $3 \times 10^{5}$ mast cells. Each point represents mean $-\leq$ S.E. of 4-6 experiments. $* \mathbf{P}<0.05, \quad * * P<0.01$ vs. immunological histamine release without drug addition.

10 and $100 \mu \mathrm{M} \mathrm{AA-344.} \mathrm{However,} \mathrm{its} \mathrm{concentration-inhibition} \mathrm{curve} \mathrm{was} \mathrm{biphasic} \mathrm{with}$ the peak inhibition at $10, / \mathrm{M}(43.3 \pm 4.4 \%, \mathrm{n}=6)$. The inhibitory effects of 0.1 and $1 \mathrm{mM}$ AA-344 were $28.0 \pm 5.2 \%(\mathrm{n}=6)$ and $22.4 \pm 4.3 \%(\mathrm{n}=6)$, respectively. AA-344 at the high concentrations did not stimulate the histamine release by itself and the decrease in its inhibitory effect was not due to artifact such as change of $\mathrm{pH}$ in the reaction mixture. DSCG showed a concentration-dependent inhibition at the range of $10 \mu \mathrm{M}$ to $1 \mathrm{mM}$, with the peak inhibition of $45.6 \pm 4.4 \%(\mathrm{n}=6)$ at $1 \mathrm{mM}$.

Histamine release induced by chemical agents: Treatment with $10 \mu \mathrm{g}$ of concanavalin A in the presence and absence of $10 \mu \mathrm{g}$ of PS released approx. 32 and $4 \%$ of the total histamine in the purified mast cells, respectively. The release was inhibited almost completely by $50 \mathrm{mM} \alpha$-methyl-D-mannoside which inhibits binding of concanavalin A to cell membrane. The histamine release induced by $10 \mu \mathrm{g}$ of concanavalin A and $10 \mu \mathrm{g}$ of PS was inhibited by AA-344 at the range of $10 \mu \mathrm{M}$ to $1 \mathrm{mM}$ in a concentration-dependent manner (Fig. 5). The 50\% inhibitory concentrations of AA-344 and DSCG were approx. 0.1 and $1 \mathrm{mM}$, respectively. Dextran at $5 \mathrm{mg}$ in the presence and absence of $50 \% \mathrm{~g}$ of PS released approx. 54 and $10 \%$ of the total histamine in the purified mast cells, respectively. Under these conditions, $0.1,0.3$ and $1 \mathrm{mM} \mathrm{AA-344}$ inhibited the release of histamine by approx. 10, 25 and 


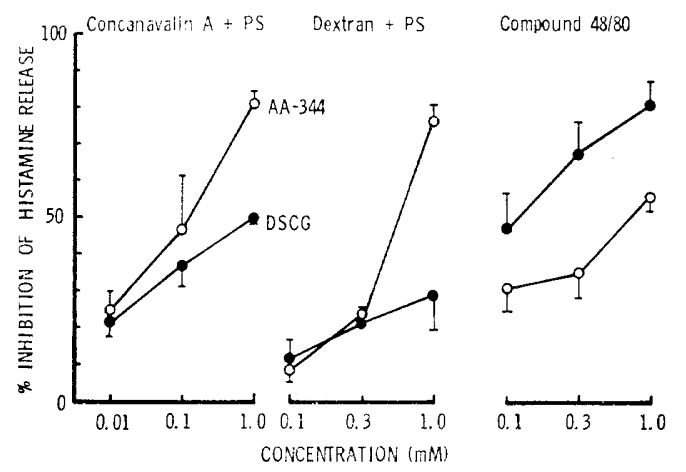

FIG. 5. Effects of AA-344 and DSCG on the histamine releases induced by concanavalin A or dextran in the presence of PS, and compound $48 / 80$ from the purified mast cells. Concanavalin A-induced histamine release: the spontaneous, $10 \mu \mathrm{g}$ PS-, $10 \mu \mathrm{g}$ concanavalin A- and concanavalin A plus PS-induced histamine releases were $2.9+2.1,9.5+2.2,4.4-1.8$ and $32.0+5.3 \%$ of the total histamine content $\left(32.6 \pm 3.3 \mu \mathrm{g} / 10^{6}\right.$ mast cells), respectively. The purity of the mast cell was $90.0 \pm 3.9 \%$. Dextran-induced histamine release: the spontaneous, $50 \mu \mathrm{g}$ PS-, $5 \mathrm{mg}$ dextran- and dextran plus PS-induced histamine releases were $2.3+0.7$, $6.9 \pm 3.1,10.3-3.8$ and $53.5+2.9 \%$ of the total histamine content $\left(18.3 \pm 1.7 \mu \mathrm{g} / 10^{6}\right.$ mast cells), respectively. The purity of the mast cell was $88.7 \pm 1.9 \%$. Compound 48/80-induced histamine release: the spontaneous and $0.25 \mu \mathrm{g}$ compound $48 / 80-$ induced histamine releases were $2.2 \pm 0.5$ and $53.6 \pm 2.2 \%$ of the total histamine content $\left(12.6 \div 2.3 \mu \mathrm{g} / 10^{6}\right.$ mast cells $)$, respectively. The purity of the mast cell was $85.0 \pm 0.8 \%$ Each point represents mean \pm S.E. of 3 experiments.

$80 \%$, respectively, but DSCG at the same concentration showed only a slight depression (Fig. 5). Compound 48/80 at $0.25 / \mathrm{g}$ induced approx. 50\% release of histamine from the purified mast cells. AA-344 at the concentration of $0.1-1 \mathrm{mM}$ showed $30-50 \%$ inhibition, whereas DSCG at the same concentration range exhibited more potent inhibitory activity than did AA-344 (Fig. 5).

\section{DISCUSSION}

The PCA reaction is caused by capillary permeability-increasing substances such as histamine released from mast cells as a result of the immunological reaction $(2,3)$. AA-344 had no inhibitory effect on the increase in the capillary permeability caused by the intradermally injected histamine (1). However, AA-344 given not only by $i . v$. route but also by p.o. route markedly inhibited the IgE-mediated PCA reaction and prevented the decrease in the histamine content at the skin site where the PCA was provoked (1). On the basis of these in vivo findings we proposed that the antiallergic action of AA-344 may be related to inhibition of the release of the chemical mediators from mast cells. The above proposal was supported by the present in vitro results that AA-344 inhibited the IgE-mediated release of histamine from the isolated peritoneal mast cells. On the other hand, the chemical agent-induced histamine release was also inhibited by AA-344 as well as DSCG at the concentration of 0.1-1 mM. AA-344 exhibited a more potent activity than DSCG on the histamine release induced by concanavalin A and dextran in the presence of PS, but the 
former was less active on the release induced by compound 48/80 than the latter. However, the inhibitory concentration of AA-344 on the histamine release induced by chemical agents was 100-1,000 times higher than that required to inhibit the IgE-mediated histamine release. Thus, this finding indicated that AA-344 as well as DSCG had a high selectivity for the latter reaction.

The immunological release of histamine from the mast cells is triggered by the antigenantibody combination. However, AA-344 did not inhibit the binding of $\operatorname{IgE}$ antibody to the receptor on the membrane surface of mast cells and the combination of antigen to IgE antibody (1). Thus, AA-344 appears to act on the membrane and/or the intracellular site involved in the releasing process of histamine following the antigen-antibody combination. It is generally accepted that microtubules play an important physiological role in secretion of granules from the secretory cells including mast cells and that $\mathrm{D}_{2} \mathrm{O}$ stimulates assembly of tubulin into microtubules and thereby accelerates the release of histamine. In the present study, colchicine, an inhibitor of microtubules formation, inhibited the IgE-mediated release of histamine regardless of the presence or absence of $\mathrm{D}_{2} \mathrm{O}$, indicating that colchicine inhibited both the basal and $\mathrm{D}_{2} \mathrm{O}$-stimulated tubulin assemblies. AA-344 as well as DSCG clearly inhibited the $\mathrm{D}_{2} \mathrm{O}$-enhanced histamine release, but a concentration required for $50 \%$ inhibition was approx. 10 times as high as that in the non-enhanced condition. These results suggest that the inhibitory action of AA-344 and DSCG on the immunological release of histamine is not due to blocking of the tubulin assembly. On the other hand, the immunological release of histamine is known to be depressed by addition of dibutyryl-cyclic AMP and by an increase in the intracellular cyclic AMP content due to the activation of adenylate cyclase or inhibition of cyclic AMP phosphodiesterase $(11,12)$. The intracellular cyclic AMP content of the mast cells when incubated with a combination of epinephrine and AA-344 increased synergistically more than 50 times in comparison with that of epinephrine or AA-344 alone and, moreover, AA-344 markedly inhibited the cyclic AMP phosphodiesterase activity in a homogenate of purified mast cells (unpublished observation). These results suggest that the antiallergic action of AA-344 may be associated with an increase in the intracellular cyclic AMP content of the mast cells as the result of an inhibition of the cyclic AMP phosphodiesterase. The inhibitory effect of DSCG on cyclic AMP phosphodiesterase in the human lymphocytes (13) and rat mast cells (14) has been reported.

The requirement of calcium for the immunological $(15,16)$ and compound $48 / 80$-induced $(17,18)$ histamine releases in mast cells is evident. Furthermore, a calcium-dependent histamine release was prevented by raising the intracellular level of cyclic AMP (19-21). DSCG, like AA-344, possessed the inhibitory activity on the cyclic AMP phosphodiesterase $(13,14)$. In addition, it was suggested that the inhibitory effect of DSCG on the histamine release was related to the membrane alteration which prevented an increase in membrane permeability of calcium stimulated by compound 48/80 (18) or calcium ionophore (22). Therefore, the mode of the action of DSCG is likely related to the prevention of calcium influx into mast cells due to elevation of the intracellular cyclic AMP level by inhibition of the cyclic AMP phosphodiesterase. The action mechanism of AA-344 on the membrane 
permeability involving calcium might be the same as that of DSCG. Recently, however, it was reported that inhibition of the calcium influx by DSCG may be questionable (23). Further studies may be required to elucidate the relationship among inhibitory effects of DSCG or AA-344 on the histamine release, elevation of cyclic AMP level and prevention of calcium influx. On the other hand, it has been reported that DSCG may be capable of stabilizing the cell membrane (24). We observed that both DSCG and AA-344 possessed a non-specific membrane stabilization activity similar to that of anti-inflammatory drugs, as these agents significantly prevented hypotonic-induced cytolysis of sheep red blood cells (25) at the dose range capable of inhibiting the compound 48/80-induced histamine release. This effect of AA-344 or DSCG may be involved in the inhibitory action of histamine release, in particular, the chemical agent-induced release.

AA-344 significantly inhibited the IgGa-mediated PCA reaction in rats, though was much less effective in comparison with that on the IgE-mediated PCA (1). In the present study, AA-344 significantly inhibited the IgGa-mediated histamine release from isolated peritoneal cells containing mast cells, though the inhibitory effect did not attain the level of more than $50 \%$, like that of DSCG. This in vitro result supports findings on the inhibitory activity on the IgGa-mediated PCA. On the other hand, the IgGa-mediated PCA in rats was inhibited by the injection of IgE antibody at the same site, suggesting a competition for the IgE receptor of mast cells $(26,27)$. Moreover, the anaphylactic release of histamine from the isolated rat mast cells was mediated not only by IgE but also by IgGa (28). These observations led to the proposal that both rat $\operatorname{IgE}$ and $\operatorname{IgGa}$ may utilize the same receptor on the mast cell or some common process leading to histamine release (26-29). However, differences between IgE and IgGa in the period for sensitization and an affinity to the binding site have also been observed (28). In fact, a significant histamine release from mast cells was induced by a simultaneous addition of antigen and antiserum containing IgGa, while at least several hours were required for sensitization with IgE in producing a considerable histamine release. Furthermore, the antigen challenge after washing of the IgGa-sensitized cells resulted in a definite reduction of the immunological histamine release in contrast to IgE-sensitized mast cells. The present results showed that the concentration-inhibition curve of AA-344 on the IgGa-mediated histamine release was biphasic with the peak inhibition of approx. $45 \%$ at the concentration of $10 / \mathrm{M}$ and that DSCG also had a partial inhibitory activity only at a high concentration $(1 \mathrm{mM})$. The difference between the inhibitory actions on the IgE- and IgGa-mediated histamine release may provide clues to determine whether or not there is a common receptor for IgE and IgGa present on the surface of the mast cells, or a common intracellular process leading to the release of histamine.

Acknowledgements: The authors are grateful to Drs. K. Shimamoto, Y. Nagawa and T. Matsumoto for pertinent discussion and to Dr. C.L. Huang for help in preparation of the manuscript. 


\section{REFERENCES}

1) Kuriki, H., Saijo, T., Maki, Y. and Kanno, M.: Antiallergic action of 6-ethyl-3-(1 $H$ tetrazol-5-yl)chromone (AA-344) on immediate hypersensitivity reaction in rats. Japan. J. Pharmacol. 29, 385-397 (1979)

2) Mота, I.: Passive cutancous anaphylaxis induced with mast cell sensitizing antibody. The role of histamine and 5-hydroxytryptamine. Life Sci. 2, 917-927 (1963)

3) Movat, H.Z.: Inflammation, Immunity and Hypersensitivity, Edited by Movat, H.Z., p. 1-130, Harper and Row Publishers, New York (1971)

4) TADA, T. AND OKumura, K.: Regulation of homocytotropic antibody formation in the rat. I. Feed-back regulation by passively administered antibody. J. Immunol. 106, 10021011 (1971)

5) Little, J.R. AND EISEN, H.N.: Methods in Immunology and Immunochemistry, Edited by Williams, C.A. And Chase, M.W., Vol. 1, p. 128-133, Academic Press, New York (1967)

6) Kekwick, R.A. And CANNAN, R.K.: XXXVI. The hydrogen ion dissociation curve of the crystalline albumin of the hen's egg. Biochem. J. 30, 227-234 (1936)

7) Sullivan, T.J., Parker, K.L., Stenson, W. and Parker, C.W.: Modulation of cyclic AMP in purified rat mast cells. I. Responses to pharmacologic, metabolic, and physical stimuli. J. Immunol. 114, 1473-1479 (1975)

8) Austen, K.F., Bloch, K.J., Baker, A.R. and Arnason, B.G.: Immunological histamine release from rat mast cells in vitro: Effect of age of cell donor. Proc. Soc. exp. Biol. Med. 120, 542-546 (1965)

9) Sullivan, T.J., Greene, W.C. and Parker, C.W.: Concanavalin A-induced histamine release from normal rat mast cells. J. Immunol. 115, 278-282 (1975)

10) Shore, P.A., Burkhalter, A. And Cohn, V.H.: A method for the fluorometric assay of histamine in tissues. J. Pharmacol. exp. Ther. 127, 182-186 (1959)

11) Lichtenstein, L.M. And Margolis, S.: Histamine release in vitro: Inhibition by catecholamincs and methylxanthines. Science 161, 902-903 (1968)

12) Lichtenstein, L.M. AND DeBernardo, R.: The immediate allergic response: In vitro action of cyclic AMP-active and other drugs on the two stages of histamine release. J. Inmunol. 107, 1131-1136 (1971)

13) Lavin, N., Rachelefsky, G.S. and Kaplan, S.A.: An action of disodium cromoglycate: Inhibition of cyclic 3',5'-AMP phosphodiesterase. J. Allergy 57, 80-88 (1976)

14) RoY, A.C. AND WARREN, B.T.: Inhibition of CAMP phosphodiesterase by disodium cromoglycate. Biochem. Pharmacol. 23, 917-920 (1974)

15) Foreman, J.C. And Mongar, J.L.: The role of the alkaline earth ions in anaphylactic histamine secretion. J. Physiol. 224, 753-769 (1972)

16) Kaliner, M. And Austen, K.F.: Cyclic AMP, ATP, and reversed anaphylactic histamine release from rat mast cells. J. Inmunol. 112, 664-674 (1974)

17) Cochrane, D.E. and Douglas, W.W.: Calcium-induced extrusion of secretory granules (exocytosis) in mast cells exposed to $48 / 80$ or the ionophores A-23187 and X-537A. Proc. natn. Acad. Sci. U.S.A. 71, 408-412 (1974)

18) Spataro, A.C. And Bosmann, H.B.: Mechanism of action of disodium cromoglycate-mast cell calcium ion influx after a histamine-releasing stimulus. Biochem. Pharmacol. 25, 505-510 (1976)

19) Lichtenstein, L.M., Levey, D.A. And Ishizaka, K.: In vitro reversed anaphylaxis: characteristics of anti-IgE mediated histamine release. Immunology 19, 831-842 (1970)

20) Loeffler, L.J., Lovenberg, W. and Sjoerdsma, A.: Effects of dibutyryl-3',5'-cyclic adenosine monophosphate, phosphodiesterase inhibitors and prostaglandin $\mathrm{E}_{1}$ on compound 48/80-induced histamine release from rat peritoneal mast cells in vitro. Biochem. Pharmacol. 20, 2287-2297 (i971)

21) Berridge, M.J.: The interaction of cyclic nucleotides and calcium in the control of cellular activity. Adv. Cyclic Nucleotides Res. 6, 58-60 (1975)

22) Johnson, H.G. AND BACH, M.K.: Prevention of calcium ionophore-induced release of histamine in rat mast cells by disodium cromoglycate. J. Immunol. 114, 514-516 (1975) 
23) Patkar, S.A., Kazimierczak, W. and Diamant, B.: Histamine release by calcium from sodium fluoride-activated rat mast cells. Further evidence for a secretory process. Int. Archs Allergy appl. Immunol. 57, 146-154 (1978)

24) Brogden, R.N., Speight, T.M. and Avery, G.S.: Sodium cromoglycate (cromolyn sodium): A review of its mode of action, pharmacology, therapeutic efficacy and use. Drugs 7, 164-282 (1974)

25) Kuriki, H., Saijo, T., Ashida, Y. and Maki, Y.: Effect of 6-ethyl-3-(1 $H$-tetrazol-5-yl) chromone (AA-344) on the immediate and delayed hypersensitivity reactions. Japan. J. Pharmacol. (in press)

26) BaCh, M.K., Bloch, K.J. AND Austen, K.F.: IgE and IgGa antibody-mediated release of histamine from rat peritoneal cells. II. Interaction of IgGa and IgE at the target cell. J. exp. Med. 133, 772-784 (1971)

27) Bloch, K.J. and Ohman, J.L.: Biochemistry of the Acute Allergic Reactions, Edited by Austen, K.F. And Becker, E.L., p. 45-64, Blackwell Scientific Publications, Oxford (1971)

28) BaCh, M.K., Bloch, K.J. and Austen, K.F.: IgE and IgGa antibody-mediated release of histamine from rat peritoneal cells. I. Optimum conditions for in vitro preparation of target cells with antibody and challenge with antigen. J. exp. Med. 133, 752-771 (1971)

29) Bach, M.K., Brashler, J.R., Bloch, K.J. and Austen, K.F.: Biochemistry of the Acute Allergic Reactions, Edited by Austen, K.F. AND BfCKer, E.L., p. 65-89, Blackwell Scientific Publications, Oxford (1971) 